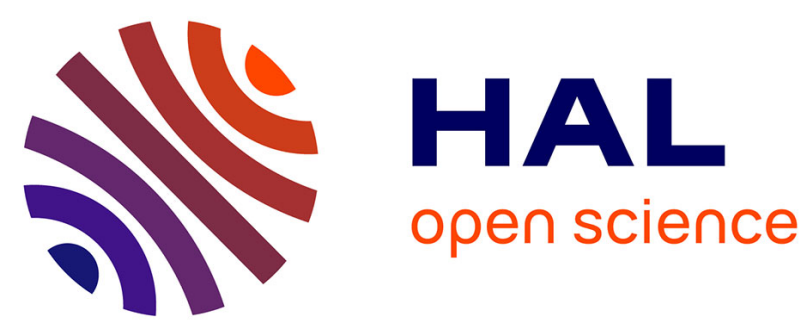

\title{
A new mutation in Muir-Torre syndrome associated with familiar transmission of different gastrointestinal adenocarcinomas
}

\author{
Miklós Tanyi, Judith Olasz, Géza Lukács, János L. Tanyi, László Tóth, Péter
} Antal-Szalmás, Zsuzsa Ress, Tamás Bubán, Csilla András, László

Damjanovich

\section{To cite this version:}

Miklós Tanyi, Judith Olasz, Géza Lukács, János L. Tanyi, László Tóth, et al.. A new mutation in MuirTorre syndrome associated with familiar transmission of different gastrointestinal adenocarcinomas. EJSO - European Journal of Surgical Oncology, 2009, 35 (10), pp.1128. 10.1016/j.ejso.2009.03.011. hal-00556293

\section{HAL Id: hal-00556293 https://hal.science/hal-00556293}

Submitted on 16 Jan 2011

HAL is a multi-disciplinary open access archive for the deposit and dissemination of scientific research documents, whether they are published or not. The documents may come from teaching and research institutions in France or abroad, or from public or private research centers.
L'archive ouverte pluridisciplinaire HAL, est destinée au dépôt et à la diffusion de documents scientifiques de niveau recherche, publiés ou non, émanant des établissements d'enseignement et de recherche français ou étrangers, des laboratoires publics ou privés. 


\section{Accepted Manuscript}

Title: A new mutation in Muir-Torre syndrome associated with familiar transmission of different gastrointestinal adenocarcinomas

Authors: Miklós Tanyi, Judith Olasz, Géza Lukács, János L. Tanyi, László Tóth, Péter Antal-Szalmás, Zsuzsa Ress, Tamás Bubán, Csilla András, László Damjanovich

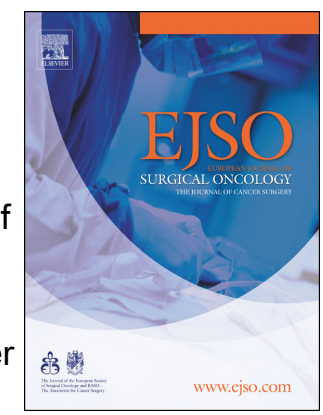

PII:

S0748-7983(09)00116-4

DOI:

10.1016/j.ejso.2009.03.011

Reference: $\quad$ YEJSO 2819

To appear in: European Journal of Surgical Oncology

Received Date: 23 August 2008

Revised Date: 24 March 2009

Accepted Date: 30 March 2009

Please cite this article as: Tanyi M, Olasz J, Lukács G, Tanyi JL, Tóth L, Antal-Szalmás P, Ress Z, Bubán T, András C, Damjanovich L. A new mutation in Muir-Torre syndrome associated with familiar transmission of different gastrointestinal adenocarcinomas, European Journal of Surgical Oncology (2009), doi: 10.1016/j.ejso.2009.03.011

This is a PDF file of an unedited manuscript that has been accepted for publication. As a service to our customers we are providing this early version of the manuscript. The manuscript will undergo copyediting, typesetting, and review of the resulting proof before it is published in its final form. Please note that during the production process errors may be discovered which could affect the content, and all legal disclaimers that apply to the journal pertain. 


\section{A new mutation in Muir-Torre syndrome associated with familiar transmission of different gastrointestinal adenocarcinomas}

Miklós Tanyi ${ }^{1 *}$, Judith Olasz ${ }^{2 *}$, Géza Lukács ${ }^{1}$, János L. Tanyi ${ }^{3}$, László Tóth ${ }^{4}$, Péter Antal-Szalmás ${ }^{5}$, Zsuzsa Ress ${ }^{6}$, Tamás Bubán ${ }^{7}$, Csilla András ${ }^{8}$, László Damjanovich $^{1}$

1. Institute of Surgery, University of Debrecen, Medical and Health Science Center, Debrecen, Hungary

2. Department of Pathogenetics, National Institute of Oncology, Budapest, Hungary

3. Department of Obstetrics and Gynecology, Baylor College of Medicine, Houston, TX, U.S.A.

4. Pathological Department, University of Debrecen, Medical and Health Science Center, Debrecen, Hungary

5. Department of Clinical Biochemistry and Molecular Pathology, University of Debrecen, Medical and Health Science Center, Debrecen, Hungary

6. $\quad 3^{\text {rd }}$ Department of Internal Medicine, University of Debrecen, Medical and Health Science Centre, Debrecen, Hungary

7. $1^{\text {st }}$ Department of Internal Medicine, University of Debrecen, Medical and Health Science Centre, Debrecen, Hungary

8. Oncological Department, University of Debrecen, Medical and Health Science Center, Debrecen, Hungary 
Corresponding author:

Miklós Tanyi M.D.

$1^{\text {st }}$ Department of Surgery, Medical and Health Science Center, University of Debrecen,

H-4012 Debrecen, Nagyerdei Krt 98, P.O.Box 27, Hungary

Tel: $36-52-418-033$

Fax: 36-52-415-517

e-mail: mtanyi@hotmail.com

* These two authors are equal first authors. 


\section{Introduction}

Hereditary Nonpolyposis Colorectal Carcinoma (HNPCC) represents about $3-6 \%$ of all colon carcinoma cases $(1,2)$. The inheritance is autosomal dominant with $80 \%$ penetrance (2). Its development is related to the germline mutations (hMLH1, hMSH2, hMSH6, hPMS1, hPMS2) of the Mismatch Repair (MMR) genes. These colorectal carcinomas typically develop at a young age and usually localize proximal to the lineal flexure $(1,2)$.

\section{Case Report}

A 57 year old male patient was presented with a papulous growth on the patient's neck, with a carcinoma of the caecum and a carcinoma of the head of the pancreas, detected on $\mathrm{CT}$ scanning. He underwent a palliative right hemicolectomy and Roux-Y bypass with a fine-needle biopsy from the pancreatic head mass. Histological results proved to be mucinous carcinoma of the caecum, adenocarcinoma of the pancreas and sebaceous carcinoma of the skin.

Further cancer cases were identifed in the family history including two colon cancers (diagnosed at age 49 and 25 years respectively), two gastric cancers (diagnosed at age 60 and 48 years respectively) and an endometrioid uterine adenocarcinoma (diagnosed at age 54 years). Per patient report, a malignant skin lesion was removed from the mother of the index person before her colon carcinoma, but exact timing and histologic diagnosis was not available (Figure 1).

Both the colon carcinoma and the skin tumor proved to be microsatellite unstable. We were not able to complete microsatellite instability investigation from the pancreatic tissue because of the insufficient quantity of the specimen. Immunohistochemistry from both the bowel, pancreas and skin samples showed 
the abscence of protein products of the hMLH1 gene in the nuclei of the tumor cells. The sequencing analysis showed a missense mutation (c.794 G>C) in exon 10 of the hMLH1 gene causing an Arg>Pro change at the amino acid position 265.

\section{Discussion}

The Muir-Torre syndrome is an autosomal dominant cancer syndrome, where the simultaneous appearance of sebaceus skin lesions and gastrointestinal malignancies is characteristic. Lynch et al. was the first in 1981 who published the association of high prevalence of skin cancers in a HNPCC family (3). Interestingly, the appearance of both benign and malignant skin lesions preceded the prognostically more important gastrointestinal malignancies $(4,5)$. Most of the time, these sebaceous lesions or keratoacanthomas are multiple and locating on the face or the neck of the patient (5). In contrast with HNPCC where the mutations are located about equally on hMLH1 and hMSH2 genes, the mutations in MTS are dominantly located on hMSH2 (6,7). The collection of family history towards HNPCC in patients with sebaceous skin lesions is highly suggested. If accumulation of GI malignancies are found in the family history, performing immunhistochemistry and microsatellite instability test from skin laesions are adviced to confirm HNPCC $(4,5,6)$ (Figure 2). Thus, the presence of sebaceous skin lesions can support the earlier diagnosis of HNPCC in families.

The prevalence of pancreatic cancer in HNPCC families is slightly higher than in the general population but this elevation is not statistically significant (8). In the literature so far just a few cases of the carcinoma of the ampulla of Vater were presented in association of Muir-Torre syndrome (9). There is only one published evidence of any association of MTS with pancreatic cancer. In a large population-based study three cases of pancreatic carcinomas were found as an associated neoplasm among 500 patients suffering from cutaneous sebaceous 
carcinoma (10). In the case presented by us there was no jaundice and the final hystological result confirmed that it was in fact a pancreatic adenocarcinoma and not a tumor of the ampulla of Vater.

In our study, a mutation in exon 10 of hMLH1 gene (c. $794 \mathrm{G}>\mathrm{C}$ ) was identified. This mutation leading to an Arg>Pro change, has not been published yet in english medical literature, and in the international databases (11). The heterodimer united from the hMLH1 and hPMS2 called MutL $\alpha$ has an important role to correct the errors generated during DNA replication (12). During this repair process MutL $\alpha$ has an ATP-dependent connection with the MutS $\alpha$ which identifies the DNA mismatches (12). Arg265 is situated in the MutS homologs interaction domain, which is an evolutionally conservative region of hMLH1. Arginine as a basic amino acid has a very polar side chain, which render it highly hidrophilic, while the Proline substituent has a cyclic aliphatic, apolar side chain, which makes it markedly different. Proline, unlike the other amino acids, has a secondary amino group, and the resulting cyclic structure may cause structural distortions. We have applied three different softwares to predict pathogenicity of this variant $(13,14,15)$. These softwares predicted this amino acid substitution to be „deleterious” (13), ,pathological” (14), and „probably damaging" (15) on the basis of sequence homology and the physical properties of amino acids. We assume that this mutation might have pathological consequence.

Five of the family members carried this mutation, just as the daughter of the index person who suffered from colon cancer at early age. This mutation was found in the son of the index person's sister who suffered from endometrial cancer and died of gastric cancer later (Figure 1). 


\section{Summary}

The unique feature of our case is that pancreas and colon cancer are associated in a patient with Muir-Torre syndrome. This unusual simultaneous appearance of these two primary tumors in MTS was not published yet in english literature. The early diagnosis and treatment in our case would have been helpful if the hereditary character of this disease had been identified earlier. Careful family history and in case of positive history, genetic testing are necessary with patient who presents sebaceous skin lesions. This followed by serial screening exam helps to identify gastrointestinal malignancies in an earlier stage. The serial screening exam must contain not just colonoscopy but gastrofiberoscopy as well because of the high risk of gastric and ampulla of Vater carcinomas among these patients. The detected mutation in this family is published first in the English literature and considered to be pathogenic.

\section{Conflict of interest}

The authors state that they have no conflict of interest.

\section{Reference}

1. Suoza RF: Review article: a molecular rationale for the how, when and why of colorectal cancer screening. Aliment Pharmacol Ther 2001;15: 451-462.

2. Lawes DA, SenGupta SB, Boulos PB: Pathogenesis and clinical management of hereditary non-polyposis colorectal cancer. British J Surg 2002;89: 1357-1369.

3. Lynch HT, Lynch PM, Pester J, Fusaro RM: The cancer family syndrome: rare cutaneous phenotypic linkage of Torre's syndrome. Arch Intern Med 1981;141: 607611.

4. Ponti G, Losi L, Pedroni M, Lucci-Cordisco E, Di Gregorio C, Pellacani G, Seidenari S: Value of MLH1 and MSH2 mutations in the appearance of Muir-Torre syndrome 
phenotype in HNPCC patients presenting sebaceous gland tumors or keratoacanthomas. J Invest Dermatol 2006;126(10): 2302-7.

5. Lynch HT, Fusaro RM, Lynch PM: Sebaceous Skin Lesions as Clues to Hereditary Non-Polyposis Colorectal Cancer. J Invest Dermatol 2006;126(10): 2158-59.

6. Ponti G, Losi L, Di Gregorio C, Roncucci L, Pedroni M, Scarselli A, Benatti P, Seidenari S, Pellacani G, Lembo L, Rossi G, Marino M, Lucci-Cordisco E, Ponz de Leon M: Identification of Muir-Torre syndrome among patients with sebaceous tumors and keratoacanthomas. Cancer 2005;103(5): 1018-1025

7. Mangold E, Pagenstecher C, Leister $\mathrm{M}$ et al.: A genotype-phenotype correlation in HNPCC: strong predominance of $\mathrm{msh} 2$ mutations in 41 patients with Muir-Torre syndrome. J Med Genet 2004;41: 567-572.

8. Watson P, Riley B: The tumor spectrum in the Lynch syndrome. Fam Cancer 2005;4:245-248.

9. Matthews JJ, Roberts R, O'Reilly DA, Schick S, Kingsnorth AN: Muir-Torre syndrome: a case for surveillance of the ampulla of Vater. Dig Surg 2002;19(1): 6566.

10. Dores GM, Curtis RE, Toro JR, Devesa SS, Fraumeni JF Jr: Incidence of cutaneous carcinoma and risk of associated neoplasms: insight into Muir-Torre syndrome. Cancer 2008;113(12): 3372-3381.

11. International Society for Gastrointestinal Hereditary Tumors, http://www.insightgroup.org

12. Plotz G, Welsch C, Giron-Monzon L, Friedhoff P, Albrecht M, Piiper A, Biondi RM, Lengauer T, Zeuzem S, Raedle J: Mutations in the MutS $\alpha$ interaction interface of MLH1 can abolish DNA mismatch repair. Nucleic Acids Research, 2006;34(22):6574-6586.

13. Sorting Intolerant from Tolerant: http://blocks.fhcrc.org/sift/SIFT.html

14. PMut: http://mmb2.pcb.ub.es:8080/PMut/

15. PolyPhen: http://genetics.bwh.harvard.edu/pph/ 
Figure legends:

Figure 1. Family tree of the proband. The proband is labeled by an arrow. Numbers below icons present the age at the diagnosis of the tumor or the age at the time of investigation. Mutation carriers labeled with R265P in the icons. CRC: colorectal cancer, EC endometrial cancer, GC: gastric cancer, SC: sebaceous carcinoma of the skin, PC: pancreatic cancer.

Figure 2. Strategy for the identification of Muir-Torre syndrome.(9) 


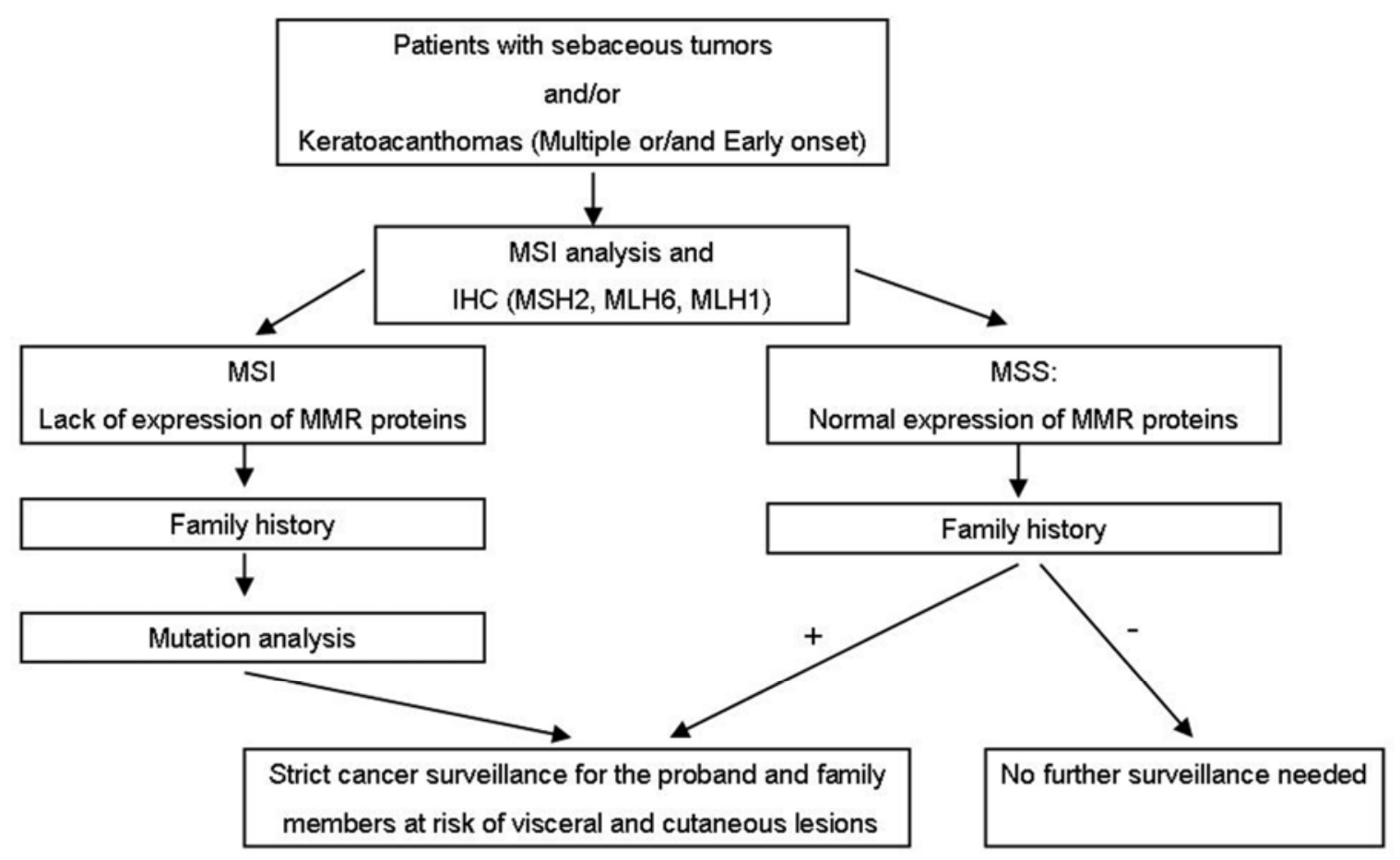




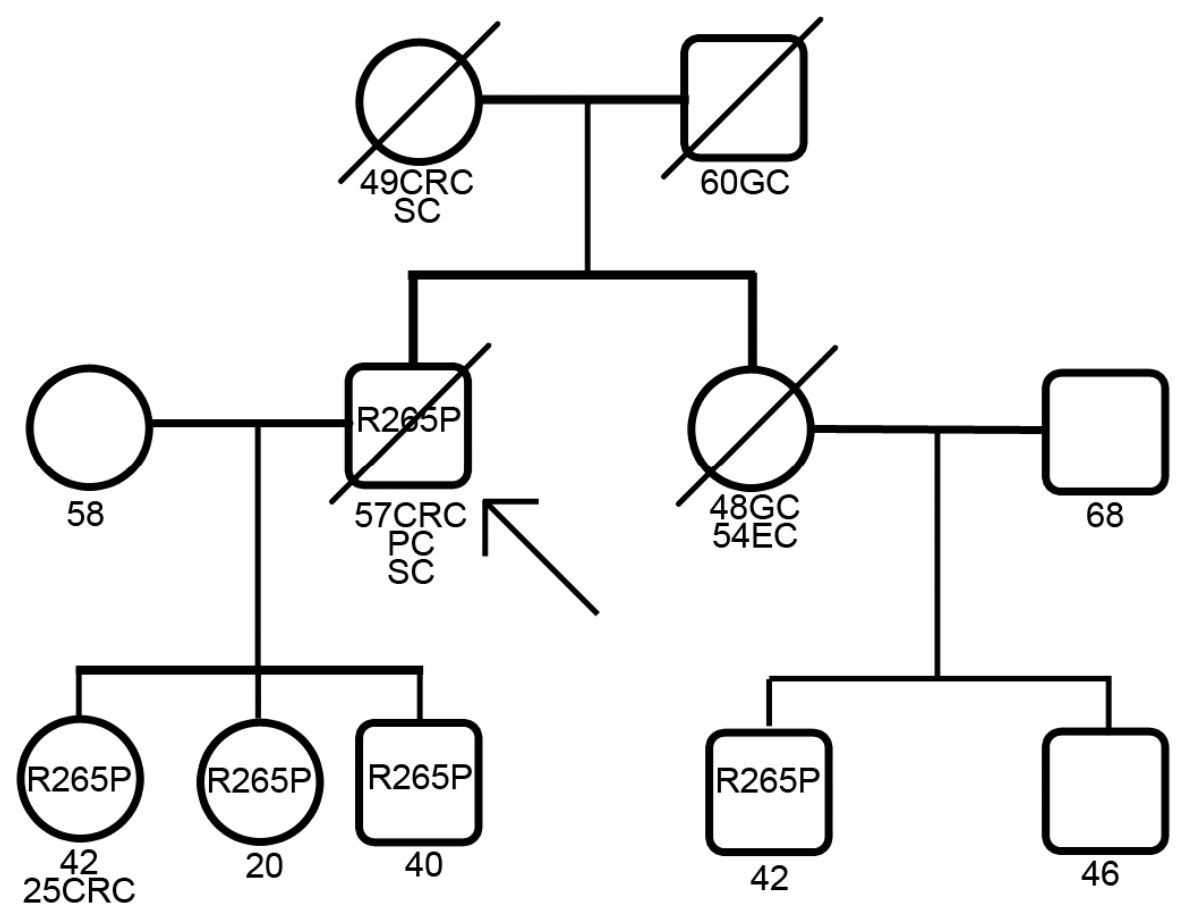

